\title{
Współczesne metody wykrywania mutacji genu EGFR jako czynnika predykcyjnego dla terapii ukierunkowanej molekularnie chorych na niedrobnokomórkowego raka płuca — czy istnieje „złoty standard" diagnostyczny?
}

\author{
Current methods to detect EGFR gene mutations as predictive factor for targeted \\ therapies in non-small cell lung cancer - is there a "golden standard" in diagnostics? \\ Działalność statutowa IGIChP, zadania nr 3/16 i 3/18
}

\begin{abstract}
According to current Polish and international recommendations, detection of EGFR gene somatic mutations is the essential part of routine diagnostic algorithm in advanced NSCLC patients considered for tyrosine kinase inhibitor therapy. Molecular heterogeneity of tumor tissue and cytology materials used for molecular diagnostics is challenging for classic methods of genetic analysis, such as Sanger sequencing, driving the development and implementation of specialized, highly sensitive techniques for mutations detection. Constant, dynamic progress in molecular biology techniques, particularly development of next-generation sequencing, should enable clinical implementation of simultaneous multiple therapeutic biomarkers analysis as well as non-invasive EGFR mutations diagnostic based on free-circulating DNA isolated from blood of non-small cell lung cancer patients.
\end{abstract}

Key words: EGFR mutations, molecular diagnostics, lung cancer, diagnostic methods

Pneumonol. Alergol. Pol. 2014; 82: 311-322

\section{Streszczenie}

Zgodnie z aktualnymi zaleceniami polskimi i międzynarodowymi, wykrywanie mutacji somatycznych genu EGFR powinno być nieodzownym etapem rutynowej diagnostyki chorych na zaawansowaną postać gruczołowego raka płuca, u których rozważana jest terapia inhibitorami kinazy tyrozynowej. Klasyczne metody analizy genetycznej, takie jak sekwencjonowanie metodą Sangera, prezentują jednak ograniczoną efektywność diagnostyczną ze względu na molekularną heterogenność materiałów tkankowych/ /cytologicznych od chorych na raka płuca. Coraz większe znaczenie w praktyce laboratoryjnej zdobywają natomiast specjalistyczne techniki analizy mutacji o wysokiej czułości detekcji, przede wszystkim oparte na PCR w czasie rzeczywistym. Stały, dynamiczny rozwój technologii stosowanych w biologii molekularnej, zwłaszcza opracowanie metod sekwencjonowania nowej generacji, pozwala oczekiwać stosunkowo szybkiego wdrożenia równoległej analizy wielu biomarkerów predykcyjnych dla nowych terapii ukierunkowanych molekularnie, a także nieinwazyjnej diagnostyki mutacji genu EGFR w pozakomórkowej frakcji DNA izolowanego z krwi obwodowej.

Słowa kluczowe: mutacje EGFR, diagnostyka molekularna, rak płuca, metody diagnostyczne

Pneumonol. Alergol. Pol. 2014; 82: 311-322

Adres do korespondencji: dr n. med. Michał Skroński, Zakład Genetyki i Immunologii Klinicznej IGiChP, ul. Płocka 26, 01-138 Warszawa, e-mail: michal.skronski@gmail.com DOI: 10.5603/PiAP.2014.0036

Praca wpłynęła do Redakcji: 11.02.2014 r.

Copyright (C) 2014 PTChP

ISSN 0867-7077 


\section{Wstęp}

Wykrywanie aktywujących mutacji genu receptora naskórkowego czynnika wzrostu (EGFR, epidermal growth factor receptor) metodami biologii molekularnej jest obecnie standardowym etapem prawidłowego postępowania diagnostycznego u chorych na gruczołowego raka płuca lub też postać mieszaną niedrobnokomórkowego raka płuca (NDRP) z dominującym utkaniem gruczołowym, u których rozważana jest terapia inhibitorami kinazy tyrozynowej EGFR (EGFRIKT). Mutacje EGFR to zmiany somatyczne typu substytucji pojedynczych nukleotydów (SNV, single nucleotide variant), niewielkich delecji lub insercji, zlokalizowane w eksonach 18-21 genu, kodujących fragment domeny kinazowej białka receptora [1]. Najczęściej wykrywanymi mutacjami aktywującymi, warunkującymi skuteczne działanie EGFR-IKT, są delecje kilku-kilkunastu nukleotydów w obrębie kodonów 746-753 w eksonie 19 genu EGFR oraz mutacja punktowa w kodonie 858 w eksonie 21, powodująca substytucję leucyny w argininę (L858R), które stanowią około 85-90\% wszystkich mutacji znajdowanych w NDRP (ryc. 1) [2]. Ze szczególnie silną odpowiedzią na leczenie TKI związane jest występowanie delecji w eksonie 19 oraz dość rzadkich podwójnych mutacji aktywujących [3]. U chorych pocho- dzenia azjatyckiego mutacje EGFR wykrywa się najczęściej, u 30-67\% badanych. Z kolei w niejednorodnej etnicznie populacji amerykańskiej częstość występowania mutacji EGFR jest szacowana na $3-25 \%$ chorych na NDRP [4]. W nieselekcjonowanej populacji chorych na NDRP rasy kaukaskiej, także w Polsce, mutacje aktywujące EGFR wykrywa się u około $10 \%$ chorych na raka gruczołowego płuca [5]. U wszystkich chorych leczonych EGFR-IKT z czasem rozwija się nabyty brak wrażliwości (oporność) na tę terapię, a jej mechanizm w co najmniej połowie przypadków jest wynikiem wystąpienia dodatkowej mutacji T790M w eksonie $20 \mathrm{w}$ uprzednio zmutowanym allelu genu EGFR [6, 7]. Mutacja T790M bywa również $(<5 \%)$ wykrywana konwencjonalnymi metodami jako zmiana pierwotna przed podjęciem terapii EGFR-IKT [8]. Innym typem mutacji warunkującym pierwotny brak wrażliwości na terapię są insercje w eksonie 20 [9].

\section{Materiał biologiczny do diagnostyki molekularnej genu EGFR}

Do diagnostyki mutacji genu EGFR wykorzystywane są materiały tkankowe oraz różnego typu materiały cytologiczne pochodzące $\mathrm{z}$ biopsji cienko- i gruboigłowych (transbronchialne, transtorakalne), wymazy szczoteczkowe z oskrzela,

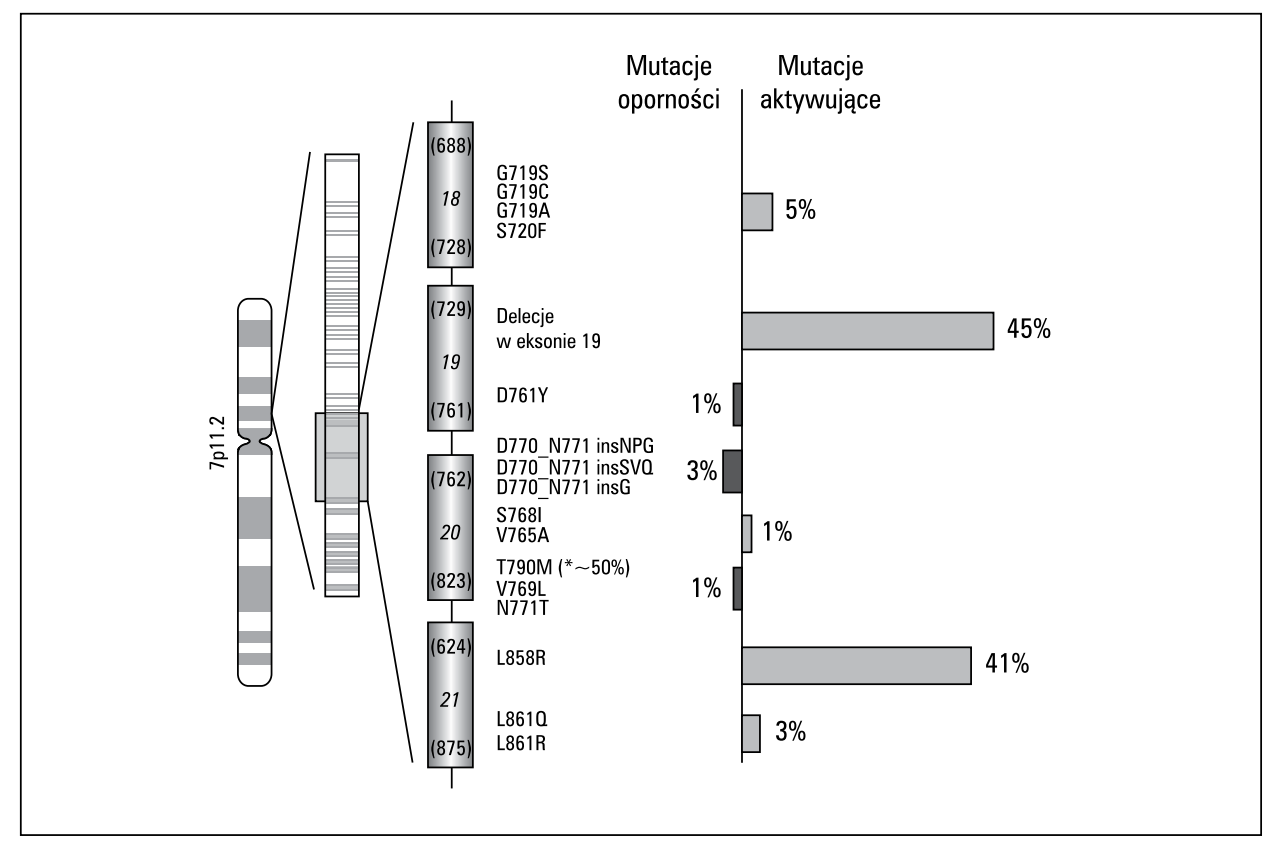

Rycina 1. Schemat prezentujący najczęstsze mutacje aktywujące i oporności w obrębie eksonów 18-21 genu EGFR [2]; *mutacja T790M jest najczęstszą ( 50\% przypadków) zmianą warunkującą wtórną oporność na leczenie EGFR-IKT

Figure 1. Scheme presenting the most common activating and resistance mutations within the EGFR gene exons 18-21 [2]; *T790M mutation is the most common ( $\sim 50 \%$ cases) genetic alteration determining acquired resistance to EGFR-TKI therapy 
osady komórek pochodzących z płynu z opłucnej, popłuczyn oskrzelowo-pęcherzykowych czy płynu osierdziowego. Czynnikami kluczowymi dla skutecznej diagnostyki są: odpowiednia liczba komórek nowotworowych w materiale oraz ich odsetek w stosunku do komórek prawidłowych [10-12]. Aktualne zalecenia wskazują, że pełną wiarygodność diagnostyczną zapewnia obecność 200-400 komórek nowotworowych w materiale [10]. W codziennej praktyce diagnostycznej kryterium to bywa trudne do spełnienia, ponieważ całkowita liczba komórek, nowotworowych i prawidłowych, uzyskiwanych za pomocą biopsji igłowych jest zwykle ograniczona do zaledwie 100-500 na jedno nakłucie [10]. Dlatego za minimalną wartość graniczną, wystarczającą do diagnostyki mutacji EGFR przyjmuje się liczbę 100 komórek nowotworowych [13]. Nie mniej istotna niż liczba komórek nowotworowych jest ich procentowa zawartość $\mathrm{w}$ materiale, na tle pozostałych, prawidłowych komórek jądrzastych. Ten parametr ma krytyczne znaczenie dla doboru odpowiednio czułej metody diagnostycznej. W materiałach o zawartości komórek nowotworowych niższej niż 50\%, czułość konwencjonalnego sekwencjonowania DNA metodą Sangera jest znacząco ograniczona. W celu zapewnienia wiarygodnej diagnostyki zaleca się wówczas makro- lub mikrodysekcję komórek nowotworowych z materiału lub stosowanie metod o wyższej czułości detekcji [10]. Jest to realny problem w praktyce klinicznej, dlatego wiele laboratoriów stosuje do wykrywania mutacji EGFR metody molekularne charakteryzujące się wyższą niż sekwencjonowanie czułością detekcji zmian somatycznych (tab. 1). Z tego samego powodu wszystkie materiały tkankowe i cytologiczne wykorzystywane do diagnostyki mutacji genu EGFR powinny być bezwzględnie poddane badaniu patomorfologicznemu celem oceny obecności komórek nowotworowych oraz ich odsetka w ogólnej populacji komórek w preparacie.

Istotnym zagadnieniem, dodatkowo komplikującym diagnostykę mutacji genu EGFR w niedrobnokomórkowym raku płuca jest potencjalna heterogenność molekularna populacji komórek nowotworowych w obrębie guza, a także możliwa niezgodność genotypu zmiany pierwotnej i przerzutów pod względem obecności mutacji EGFR [15, 16]. Mimo to, zgodnie z najnowszymi zaleceniami do oznaczania mutacji genu EGFR u chorych na raka płuca mogą być wykorzystywane materiały zarówno z guza pierwotnego, jak i przerzutu odległego lub do węzłów chłonnych, przy czym zawsze preferowany jest materiał uzyskany podczas ostatniego zabiegu [11]. Należy zauważyć, że analiza materiałów z węzłów chłonnych może być utrudniona ze względu na częstą obecność dużej liczby jądrzastych komórek limfoidalnych. Aktualne zalecenia nie wskazują na praktyczną potrzebę analizy więcej niż jednego fragmentu tej samej zmiany nowotworowej [11].

W praktyce klinicznej, diagnostyka mutacji genu EGFR jest przeprowadzana najczęściej w materiale biopsyjnym lub tkankowym utrwalonym $\mathrm{w}$ formalinie i zatopionym w bloczku parafinowym (FFPE, formalin-fixed paraffin-embedded), a także w materiale cytologicznym w postaci cytobloków i rozmazów. Standardowa obróbka materiału tkankowego przez utrwalanie w 4-procentowej buforowanej formalinie i zatapianie w bloczkach parafinowych obniża analityczną jakość kwasów nukleinowych. Czas inkubacji $\mathrm{w}$ formalinie jest proporcjonalny do wielkości materiału i ma bezpośrednie przełożenie na stopień degradacji DNA. W związku z powszechnym wykorzystywaniem preparatów FFPE do oznaczeń molekularnych, zalecana jest standaryzacja postępowania z różnymi typami materiałów, na przykład do 6-12 godzin inkubacji $\mathrm{w}$ formalinie $\mathrm{w}$ przypadku małych biopsji oraz 8-18 godzin przy utrwalaniu dużych fragmentów tkanki [10, 11]. Fragmentacja kwasów nukleinowych, zmniejszająca wydajność reakcji PCR i w efekcie reprezentatywność próbki materiału diagnostycznego, stwarza wymóg zastosowania szczególnie wydajnych procedur izolacji DNA, zwłaszcza dla materiałów skąpokomórkowych. Obecnie dostępne są liczne zestawy komercyjne oparte na różnych systemach izolacji kwasów nukleinowych, pozwalające na wysoki stopień standaryzacji. Obiektywne analizy, biorące pod uwagę odzysk DNA z materiału biologicznego, jego fragmentację i stopień hamowania reakcji PCR, wskazują na relatywnie wysoką jakość DNA otrzymywanego metodą opartą na kolumienkach ze złożem krzemionkowym [17].

\section{Metody wykorzystywane w diagnostyce mutacji genu EGFR}

Nowoczesna diagnostyka mutacji genu EGFR jest oparta przede wszystkim na technikach molekularnych, wykorzystujących amplifikację DNA metodą łańcuchowej reakcji polimerazy (PCR, polymerase chain reaction), zróżnicowanych pod względem sposobu detekcji zmutowanego allelu, co z kolei ma bezpośrednie przełożenie na ich czułość analityczną. Najogólniej można je podzielić na metody bezpośrednie, umożliwiające detekcję dowolnych zmian w analizowanej sekwencji, 
oraz metody pośrednie, pozwalające jedynie na wykrywanie mutacji wcześniej zdefiniowanych. Metody bezpośrednie polegają na analizie sekwencji nukleotydowej genomowego DNA i należą do nich klasyczne sekwencjonowanie metodą Sangera, a także nowoczesne i wprowadzane obecnie do diagnostyki sekwencjonowanie nowej generacji (NGS, next-generation sequencing). Metody pośrednie opierają się przede wszystkim na różnego typu sondach molekularnych, analizie konformacji DNA lub cięciu enzymami restrykcyjnymi w celu eliminacji DNA o sekwencji allelu natywnego (wild-type). Zarówno optymalizacja lub modyfikacja istniejących, jak również rozwój wielu nowych metod molekularnych i ich skuteczne wykorzystanie w diagnostyce mutacji somatycznych nowotworów ma na celu eliminowanie typowych błędów i trudności technicznych związanych z detekcją zmian genetycznych $\mathrm{w}$ materiałach biologicznych wykorzystywanych rutynowo w praktyce klinicznej.

Wiele spośród obecnie stosowanych metod molekularnych charakteryzuje się porównywalną efektywnością diagnostyczną, a aktualne zalecenia nie wskazują żadnej z nich w sposób jednoznaczny, zwracając jednak uwagę na kluczowy parametr czułości detekcji w stosunku do zawartości komórek nowotworowych w materiale [10]. Wybór metody diagnostyki mutacji EGFR pozostaje zatem $\mathrm{w}$ gestii laboratorium i wynika z jego wyposażenia oraz doświadczenia personelu. Jednocześnie należy podkreślić, że warunkiem niezbędnym do prowadzenia diagnostyki w zakresie mutacji EGFR jest odpowiednia walidacja testu i/lub korzystanie z metody certyfikowanej do diagnostyki in vitro (CE-IVD) [10]. Poszczególne metody różnią się także czasem trwania i stopniem złożoności procedury wykonania, znajdującymi odzwierciedlenie w czasie oczekiwania na wydanie wyniku diagnostycznego (TAT, turn -around time) (ryc. 2) [18].

W dalszej części niniejszego artykułu przedstawiono systematyczne omówienie metod i technik molekularnych stosowanych obecnie w diagnostyce mutacji EGFR.

\section{Metody bezpośrednie}

Jako metody bezpośrednie detekcji mutacji określamy techniki molekularne umożliwiające ustalenie sekwencji wybranego fragmentu DNA bezpośrednio poprzez odczyt kolejności nukleotydów, przez co mogą być stosowane do analizy genetycznej zarówno znanych mutacji, jak i jako narzędzie odkrywania nowych zmian genetycznych.

\section{Sekwencjonowanie DNA metodą Sangera (dideoksy)}

Metoda sekwencjonowania DNA poprzez terminację wydłużania łańcucha DNA z wykorzystaniem dideoksynukleotydów została opracowana w roku 1977 przez Fredericka Sangera [19]. Jest ona klasyczną i najszerzej obecnie wykorzystywaną metodą detekcji zmian w sekwencji DNA (direct sequencing, Sanger sequencing), przede wszystkim w przypadku analizy mutacji w dziedzicznych zaburzeniach genetycznych. Idealnie nadaje się do analizy produktów reakcji PCR, ponieważ umożliwia odczyt sekwencji nukleotydów we fragmencie DNA o długości od około 100 do ponad 1000 par zasad. Jest to technika szeroko stosowana do analizy sekwencji DNA w poszukiwaniu mutacji pojedynczych nukleotydów, a także niewielkich delecji i insercji. Sekwencjonowanie metodą Sangera pozwala na bezpośrednie wykrycie dowolnej mutacji w analizowanej sekwencji DNA, zarówno w przypadku znanych, jak i nowych zmian genetycznych. Mimo wysokiej specyficzności, posiada ona szereg wad ograniczających jej wykorzystanie $\mathrm{w}$ detekcji mutacji somatycznych w nowotworach. Metoda ta jest praco- i czasochłonna, gdyż wymaga wykonania wielu następujących po sobie procedur (amplifikacja DNA, reakcja sekwencjonowania, rozdział elektroforetyczny w sekwenatorze kapilarnym, analiza sekwencji DNA) (ryc. 2). Podstawowym problemem ograniczającym jej zastosowanie w diagnostyce mutacji somatycznych genu EGFR jest jednak relatywnie niska czułość. W optymalnych warunkach, wykorzystując matrycę DNA o wysokiej jakości, sekwencjonowanie metodą Sangera może osiągać czułość detekcji do 20-25\% zmutowanego allelu genu EGFR. Wiele materiałów diagnostycznych, przede wszystkim utrwalonych FFPE, charakteryzuje się jednak wysokim stopniem degradacji DNA, co ma istotnie negatywny wpływ na odczyt i interpretację analizowanej sekwencji. Zaleca się zatem, aby w praktyce diagnostycznej metodą sekwencjonowania kapilarnego analizować jedynie materiały zawierające przynajmniej 50\% komórek nowotworowych [10].

\section{Sekwencjonowanie nowej generacji}

Wprowadzane do diagnostyki techniki sekwencjonowania nowej generacji (NGS, nextgeneration sequencing) pozwalają na osiągnięcie wyższej niż metoda Sangera czułości detekcji zmian genetycznych oraz równoczesną analizę 


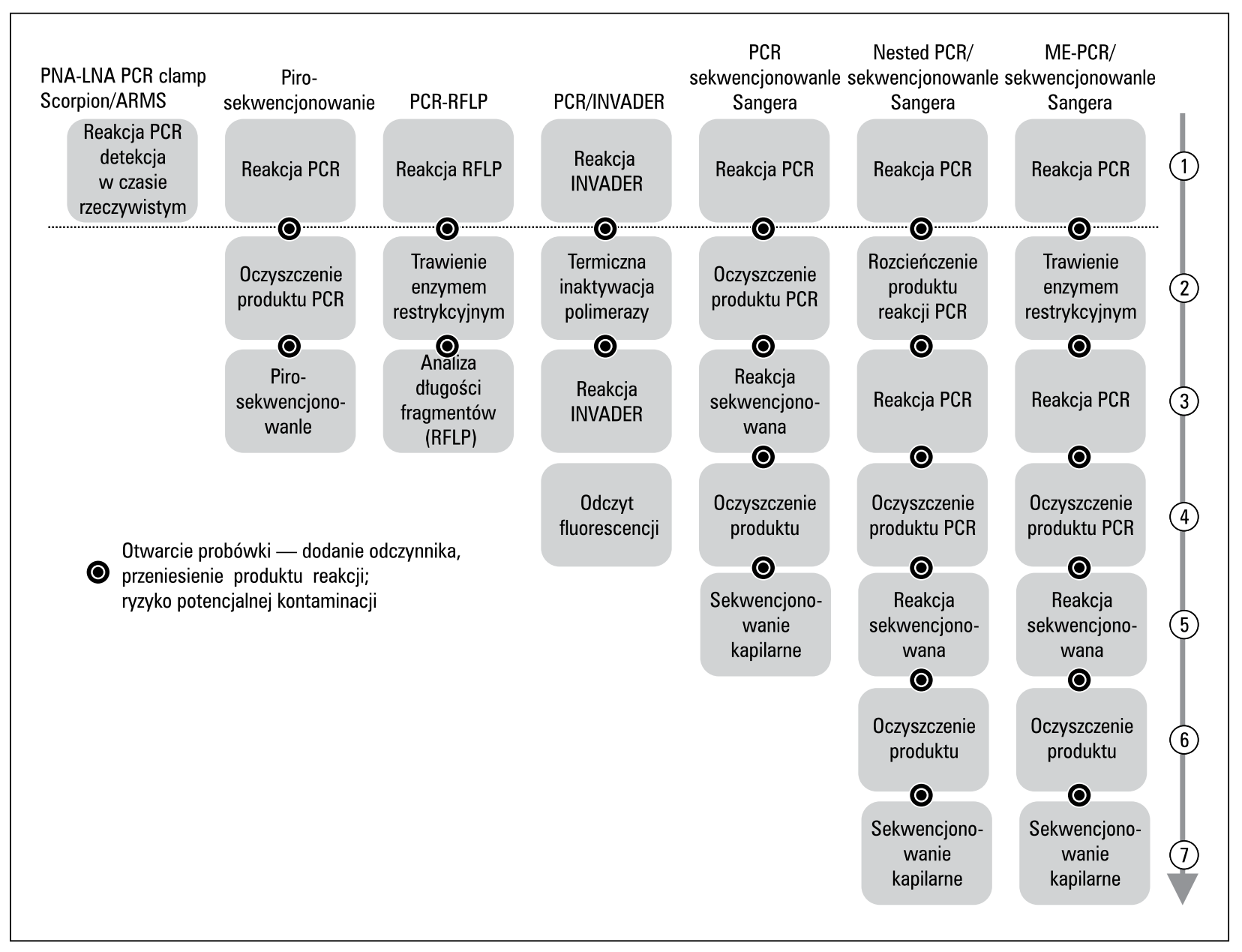

Rycina 2. Porównanie procedur analizy mutacji EGFR z wykorzystaniem wybranych metod molekularnych: PNA-LNA PCR clamp, Scorpion ARMS, pirosekwencjonowania, analizy długości fragmentów restrykcyjnych (RFLP), PCR-Invader, sekwencjonowania produktów PCR metodą Sangera oraz mutant-enriched PCR (ME-PCR) z odczytem sekwencji metodą sekwencjonowania [18]

Figure 2. Comparison of the procedures of EGFR mutation analysis by molecular methods: PNA-LNA PCR clamp, Scorpion ARMS, pyrosequencing, restriction fragments length polymorphism (RFLP), PCR-Invader, Sanger sequencing and mutant-enriched PCR (ME-PCR) with Sanger sequencing detection [18]

wszystkich mutacji w eksonach 18-21 genu EGFR. Umożliwiają również możliwość ilościowego pomiaru zawartości zmutowanego allelu w badanym materiale. Wysoka przepustowość platform sekwencjonowania nowej generacji pozwala na analizę nie tylko mutacji EGFR, ale także jednoczesne wykrywanie zmian w sekwencjach kilkudziesięciu lub nawet kilkuset genów.

Obecnie najpopularniejszymi platformami sekwencjonowania nowej generacji, wykorzystywanymi między innymi w diagnostyce mutacji EGFR, są sekwenatory GS Junior, (pirosekwencjonowanie), Ion Torrent PGM (semicinductor sequencing, sekwencjonowanie na podstawie technologii półprzewodnikowej) oraz MiSeq (sekwencjonowanie przez syntezę). Ich zaletą jest wysoka wydajność i możliwość równoczesnej analizy wielu materiałów, co pozwala znacząco obniżyć koszty. Dostępne są zestawy umożliwiające amplifikację eksonów 18-21 genu EGFR w pojedynczej reakcji PCR (multiplex PCR), ale również jednoczesną amplifikację fragmentów DNA zawierających sekwencje szeregu innych genów potencjalnie istotnych z klinicznego punktu widzenia.

Ze względu na wciąż wysoki koszt aparatury i oznaczeń, faktyczna dostępność metod opartych na sekwencjonowaniu nowej generacji jest obecnie znikoma [20]. Opracowanie i wprowadzenie nowych leków dla ukierunkowanych molekularnie terapii chorych na NDRP spowoduje jednak w przyszłości konieczność oznaczania większej liczby markerów genetycznych, a tym samym wymusi stosowanie metod o wysokiej przepustowości. 


\section{Metody pośrednie}

Ograniczona czułość detekcji mutacji somatycznych EGFR charakteryzująca sekwencjonowanie metodą Sangera znacząco utrudnia analizę mutacji w materiałach tkankowych i cytologicznych od chorych na NDRP. Zgodnie z aktualnymi wytycznymi, alternatywą dla sekwencjonowania mogą być metody charakteryzujące się wysoką czułością detekcji zmutowanego allelu genu EGFR, identyfikujące nie kolejność występowania nukleotydów w DNA, lecz konkretne mutacje. Metody te wykorzystują: 1) selektywne namnażanie zmutowanego allelu; 2) fluorescencyjne sondy molekularne specyficznie rozpoznające sekwencję zmutowanego allelu; 3) analizę zmian struktury DNA (długości fragmentów, masy, konformacji) lub 4) detekcję białka receptora EGF o zmienionej sekwencji aminokwasowej. Większość pośrednich metod detekcji pozwala na wykrycie jedynie znanych mutacji genu EGFR. Badane są przede wszystkim mutacje najczęstsze i najlepiej scharakteryzowane z farmakogenetycznego i klinicznego punktu widzenia w kontekście odpowiedzi na leczenie IKT.

\section{Allelospecyficzna amplifikacja}

Metody oparte na allelospecyficznej amplifikacji PCR znacząco podnoszą czułość detekcji zmutowanego allelu dzięki selektywnemu zwiększeniu liczby jego kopii w roztworze reakcyjnym. Cel ten może zostać osiągnięty różnymi metodami, na przykład poprzez pozytywną selekcję zmutowanej sekwencji DNA z wykorzystaniem starterów PCR specyficznych dla poszukiwanego allelu
(ASP-PCR, allele-specific primer PCR), hybrydowych sond fluorescencyjnych selektywnie amplifikujących i wykrywających zmutowany allel (Scorpion-ARMS, Scorpion Amplified Refractory Mutation System), a także poprzez wykorzystanie różnic w temperaturze topnienia homo- i heterodupleksów DNA (COLD-PCR, CO-amplification at Lower Denaturation temperature-Polymerase Chain Reaction) [21-23]. Selekcja zmutowanego allelu bywa też negatywna i dokonuje się poprzez blokowanie amplifikacji DNA typu natywnego, na przykład przez użycie antysensownych cząsteczek kwasu peptydonukleinowego (PNA, peptide nucleic acid) w metodach PNA-LNA PCR clamp, PNA clamp oraz PNA-SmartAmp2 czy też eliminację DNA o sekwencji natywnej za pomocą enzymu restrykcyjnego (ME-PCR, mutant-enriched PCR) [24-27].

Warto wspomnieć, że w przypadku allelospecyficznej amplifikacji DNA, dla wykrycia zmutowanego allelu wykorzystywane są zróżnicowane techniki detekcji, przede wszystkim PCR w czasie rzeczywistym (PNA-LNA PCR clamp, ScorpionARMS, PCR-Invader, COLD-PCR), a także sekwencjonowanie produktów allelospecyficznej reakcji PCR (PNA-LNA PCR clamp, ME-PCR, COLD-PCR) czy elektroforeza kapilarna (SNaPshot, ASP-PCR).

Allelospecyficzna amplifikacja pozwala na osiągnięcie bardzo wysokiej czułości detekcji, sięgającej nawet poniżej 1\% zmutowanego allelu w mieszaninie DNA genomowego (tab. 1). Wysoka czułość, w powiązaniu z szybką i prostą procedurą wykonania, zapewniają wyjątkową efektywność metod wykorzystujących allelospecyficzną amplifikację DNA i fluorescencyjną detekcję zmutowanego allelu EGFR również

Tabela 1. Charakterystyka powszechnie stosowanych metod diagnostycznych z uwzględnieniem czułości detekcji oraz wykrywanych mutacji [14]. Angielskie nazwy metod podano z powodu braku polskich odpowiedników

Table 1. The features of common diagnostics methods with reference to their sensitivity and mutations identified [14]

\begin{tabular}{ccc}
\hline Technika & Czułość detekcji (\% zmutowanego allelu) & Identyfikowane mutacje \\
\hline Sekwencjonowanie metodą Sangera & maks. ok. 20-25\% & Znane i nowe \\
Sondy hydrolizujące (real-timePCR) & $5-10 \%$ & Tylko znane \\
PCR-SSCP & $5 \%$ & Znane i nowe \\
dHPLC & $5 \%$ & Znane i nowe \\
PCR-RFLP & $5 \%$ & Tylko znane \\
PNA-LNA PCR clamp & $1 \%$ & Znane i nowe \\
Scorpion ARMS & $1 \%$ & Tylko znane \\
Mutant-enriched PCR & $0,1 \%$ & Tylko znane \\
\hline
\end{tabular}

PCR (polymerase chain reaction) — tańcuchowa reakcja polimerazy; SSCP (single strand conformation polymorphism) — analiza polimorfizmu konformacji jednoniciowych fragmentów DNA; dHPLC (denaturing high performance liquid chromatography) — denaturująca wysokosprawna chromatografia cieczowa; ARMS — Amplifiacation-Refractory Mutation System; PNA-LNA PCR clamp — Peptide Nucleic Acid-Locked Nucleic Acid PCR clamp 
w materiałach drobnych i o niskiej jakości DNA, takich jak utrwalone FFPE biopsje przerzutów do ośrodkowego układu nerwowego [28]. Umożliwia to de facto analizę diagnostyczną wszystkich materiałów zawierających odpowiednio reprezentatywną liczbę komórek nowotworowych [10, 29].

\section{Metody oparte na sondach molekularnych}

Sondy molekularne są klasyczną, powszechnie stosowaną w biologii molekularnej techniką detekcji określonej sekwencji DNA/RNA, wykorzystywaną zarówno w klasycznych technikach typu „Southern blot” czy „Northern blot” oraz FISH (fluorescence in situ hybridization), jak i nowoczesnych metodach opartych na PCR w czasie rzeczywistym. Użycie krótkich, wyznakowanych fluorescencyjnie fragmentów DNA o sekwencji komplementarnej do zmutowanego allelu jako sond hydrolizujących (typu TaqMan ${ }^{\circledR}$ ) lub hybrydyzujących (typu LightCycler ${ }^{\circledR}$ ) pozwala na osiągnięcie czułości detekcji rzędu 5-10\% zmutowanego allelu EGFR w mieszaninie genomowego DNA typu natywnego (tab. 1). Dodatkowe modyfikacje sekwencji sondy, na przykład dodanie zasad LNA (locked nucleic acid) lub znakowanie MGB (minor groove binder probes), dodatkowo podnoszą specyficzność i siłę wiązania określonej sekwencji DNA, a w konsekwencji czułość detekcji zmutowanego allelu [30].

Bardzo interesującą metodą detekcji mutacji somatycznych w onkogenach jest BEAMing (Beads, Emulsion, Amplification and Magnetics). Wykorzystuje ona wiązanie pojedynczych cząsteczek DNA do powierzchni magnetycznych kuleczek i ich klonalną amplifikację za pomocą emulsyjnego PCR oraz odczyt sygnału fluorescencyjnego z wykorzystaniem cytometru przepływowego [31, 32]. Niezwykle wysoka czułość detekcji prezentowana przez tę technikę predestynuje ją do detekcji zmutowanego allelu w mieszaninie DNA zawierającej znaczną przewagę allelu natywnego.

Inną nowoczesną metodą wysokoczułej detekcji mutacji występujących w niewielkiej liczbie kopii $\mathrm{w}$ analizowanej mieszaninie DNA jest „digital PCR”. Metoda ta oparta jest na namnażaniu klonów pojedynczych cząsteczek DNA w wielokrotnych równoległych reakcjach PCR zachodzących w mikroskopijnych kroplach roztworu reakcyjnego o objętości nanolitrów. Metoda ta pozwala nie tylko z wysoką czułością wykrywać obecność nielicznych klonów komórek w obrębie guza, zawierających mutację genu
EGFR, ale także może służyć do pomiaru ilościowego zawartości zmutowanego allelu oraz liczby kopii genu [33].

W diagnostyce mutacji EGFR stosowane są także rozliczne wysokoczułe metody detekcji wykorzystujące, oprócz sond molekularnych, właściwości enzymatyczne białek rozpoznających określone struktury kwasów nukleinowych, między innymi RNAzy H (Cycleave PCR) oraz endonukleazy FEN (Flap Endonuclease) w metodzie PCR-Invader [34, 35].

\section{Analiza struktury fragmentu cząsteczki DNA}

Wiele technik molekularnych i biofizycznych pozwala na wykrycie mutacji w sekwencji cząsteczki DNA amplifikowanego metodą PCR. Przykładowo, wystąpienie delecji w analizowanej sekwencji DNA prowadzi do skrócenia produktu reakcji PCR o określoną liczbę nukleotydów, co można potwierdzić na przykład za pomocą elektroforezy kapilarnej w żelu poliakrylamidowym. Również bardziej subtelne różnice, jak substytucja pojedynczego nukleotydu, powodują między innymi zmianę masy cząsteczki i konformacji DNA wykrywane odpowiednio wysokospecjalistyczną techniką spektrometrii masowej MALDI-TOF (matrix-assisted laser desorption ionisation-time of flight) oraz podczas elektroforezy w zmiennym polu elektrycznym (SSCP, single stand conformation polymorphism) [36, 37]. Odmienny skład nukleotydowy cząsteczki DNA powoduje także zmianę jej temperatury topnienia, co wykorzystywane jest w detekcji mutacji metodą HRM (high-resolution melting) lub wysokociśnieniowej chromatografii cieczowej (dHPLC, denaturing High-Pressure Liquid Chromatography) [38-40].

\section{Detekcja zmutowanego białka EGFR metodą immunohistochemiczną}

Ponieważ aktywujący charakter mutacji EGFR wynika ze zmiany sekwencji kodowanego białka, a przez to struktury domeny kinazowej receptora, potencjalną alternatywą dla molekularnych metod diagnostycznych opartych na analizie DNA mogłaby być identyfikacja zmutowanego białka EGFR z wykorzystaniem specyficznych przeciwciał [41]. Hasanovic i wsp. osiągnęli 100-procentową dodatnią wartość predykcyjną oraz specyficzność przeciwciał wykrywających delecje w eksonie 19 EGFR oraz mutację L858R w materiałach cytologicznych, biopsyjnych, a także odwapnionych biopsjach przerzutów do 
kości [42]. Wyniki badań w materiale pobranym podczas zabiegu operacyjnego (resekcyjnym) były znacznie mniej zadowalające. Kitamura i wsp., analizując 238 materiałów resekcyjnych raka płuca, wykazali czułość 92\% oraz specyficzność 37\% detekcji delecji w eksonie 19 oraz mutacji L858R, a także stwierdzili 4 fałszywie pozytywne wyniki (dodatnie barwienie w preparatach bez potwierdzonej mutacji na poziomie DNA). Przeciwciała wykrywające białko z mutacją wykazywały minimalnie wyższą czułość i specyficzność diagnostyczną dla delecji niż dla substytucji L858R (odpowiednio 99\% i 40\% v. 97\% i 36\%) [43]. Również Brevet i wsp. wykazali 95-procentową czułość detekcji białka EGFR z substytucją aminokwasową L858R przy poziomie ekspresji białka $1+$ oraz $76 \%$ przy poziomie $2+$. W przypadku białek EGFR z delecją inną niż delE746-750, ogólna czułość wykrywania delecji w eksonie 19 wynosiła $85 \%$ przy poziomie wybarwienia $1+$ i $67 \%$ przy $2+$ [44]. Należy zauważyć, że w przypadku oznaczeń immunohistochemicznych możliwe jest efektywne wykrycie jedynie najczęstszych mutacji, L858R oraz delE746-A750, a czułość diagnostyczna zależy w dużej mierze od subiektywnej interpretacji wyniku badania [45]. Przeciwciała dla zmutowanego białka EGFR nie są zatem obecnie stosowane $\mathrm{w}$ rutynowej diagnostyce, wymagają dalszej walidacji i standaryzacji interpretacji wyników diagnostycznych.

\section{Stosowanie metod wysokoczułych versus sekwencjonowanie metodą Sangera}

Stosowanie wysokoczułych metod detekcji mutacji genu EGFR ma wiele zalet, do których można zaliczyć możliwość wykonywania wiarygodnej analizy w materiałach o skąpej zawartości komórek nowotworowych. Istnieją jednak obawy, że stosowanie wysokoczułych technik molekularnych do badania materiałów o wysokiej zawartości komórek nowotworowych (> 50\%) identyfikuje również nieliczne klony komórkowe ze zmutowanym EGFR na tle ogólnej populacji komórek guza o natywnym genotypie, co może skutkować nieadekwatną/brakiem odpowiedzi na leczenie EGFR-IKT [46]. Zhou i wsp. przy użyciu wysokoczułej metody ARMS-PCR oraz konwencjonalnego sekwencjonowania Sangera analizowali materiały tkankowe pobrane od 100 chorych na NDRP, które charakteryzowała przynajmniej 50\% zawartości komórek nowotworowych [47]. W grupie chorych, u których mutację EGFR potwierdzono dwiema metodami obserwowano istotnie dłuższy czas przeżycia wolnego od pro- gresji (PFS, progression-free survival) w stosunku do grupy, w której mutację wykryto jedynie wysokoczułą techniką ARMS-PCR (negatywny wynik sekwencjonowania; $p=0,014$ ). Z kolei Taniguchi i wsp. obserwowali, że w grupie chorych na NDRP z wysokim stopniem heterogenności pod względem mutacji $E G F R$ w materiale tkankowym czas bez wznowy oraz przeżycie po leczeniu gefitynibem były znacząco krótsze niż w grupie bez genetycznej heterogenności EGFR [14].

Również w analizie najczęstszej mutacji warunkującej brak wrażliwości na leczenie EGFRIKT, częstość detekcji mutacji T790M była bezpośrednio uzależniona od czułości zastosowanej techniki molekularnej i wynosiła odpowiednio $25,5 \%$ dla metody wysokoczułej (spektrometria MALDI-TOF, sekwencjonowanie nowej generacji) oraz zaledwie $2,8 \%$ dla sekwencjonowania metodą Sangera [36]. Wynik tego badania wykazał również, że obecność mutacji T790M przed leczeniem EGFR-IKT jest niezależnym negatywnym czynnikiem predykcyjnym, ściśle powiązanym z istotnie krótszym czasem przeżycia wolnego od progresji [36]. Powyższe wyniki zdają się jednoznacznie potwierdzać możliwość występowania de novo w guzie pierwotnym niewielkiego odsetka klonów komórek nowotworowych, zawierających mutację aktywującą genu EGFR lub mutację T790M, warunkującą brak wrażliwości na EGFR-IKT oraz postulowany wpływ ich detekcji na skuteczność stosowania EGFR-IKT u chorych na raka płuca. W myśl obecnych zaleceń, badanie mutacji genu EGFR ma charakter jakościowy (oceniana jest obecność lub brak mutacji EGFR). Coraz lepiej rozumiana jest jednak potrzeba wdrożenia do rutynowej diagnostyki metod umożliwiających pomiar ilościowy zmutowanego allelu, pośrednio dostarczających informację na temat spodziewanej efektywności leczenia ukierunkowanego molekularnie.

Warto wspomnieć, że PNA-LNA PCR clamp jest jedyną metodą wykorzystującą PCR w czasie rzeczywistym, która pozwala na bezpośrednie sekwencjonowanie produktu reakcji PCR. Dzięki temu możliwa jest alternatywna weryfikacja uzyskanego wyniku diagnostycznego za pomocą metody bezpośredniej, pozwalająca między innymi na wysokoczułą detekcję rzadkich mutacji EGFR [48].

\section{Interpretacja wyników rozbieżnych}

Złożoność molekularna materiałów diagnostycznych i odmienna charakterystyka metod detekcji mutacji genu EGFR mogą prowadzić do 
rozbieżności wyników otrzymanych różnymi metodami. Jak wspominano powyżej, rozbieżności mogą wynikać, z różnej czułości detekcji zmutowanego allelu prezentowanej przez stosowane metody diagnostyczne.

Bardzo cennych informacji dotyczących realnej efektywności rutynowej diagnostyki molekularnej z wykorzystaniem różnych metod detekcji mutacji genu EGFR dostarczają wyniki wieloośrodkowych badań walidacyjnych. W badaniu opublikowanym przez Tysarowskiego i wsp. w roku 2010 brało udział 5 polskich ośrodków, wykorzystujących do diagnostyki mutacji EGFR zróżnicowane metody: sekwencjonowanie metodą Sangera (3 ośrodki), analizę długości fragmentów i ASP-PCR (1 ośrodek), SNaPshot i HRM (1 ośrodek). Wszystkie ośrodki uzyskały zgodne wyniki analizy materiałów, poprawnie identyfikując obecność 5 mutacji EGFR w DNA izolowanym z materiałów w bloczkach parafinowych [49].

$\mathrm{Z}$ kolei w badaniu prowadzonym przez Włoskie Towarzystwo Onkologi Medycznej (AIOM, Italian Association for Medical Oncology) oraz Włoskie Towarzystwo Patologii i Cytologii, procedurze zewnętrznej kontroli jakości (EQA, External Quality Assessment) poddano 47 ośrodków wykonujących diagnostykę mutacji EGFR, wykorzystując materiały tkanek utrwalonych FFPE zwalidowane uprzednio przez 3 niezależne ośrodki [50]. Trzydzieści siedem ośrodków wykorzystywało sekwencjonowanie metodą Sangera, 8 pirosekwencjonowanie, zaś 2 ośrodki metodę opartą na PCR w czasie rzeczywistym. W pierwszej części badania aż 14/47 (30\%) laboratoriów nie osiągnęło wymaganego minimum 18/20 punktów przyznawanych za poprawny wynik diagnostyczny, wszystkie prowadziły diagnostykę w oparciu o sekwencjonowanie metodą Sangera. Z kolei 10/10 ośrodków stosujących metody o wysokiej czułości, pirosekwencjonowanie lub PCR w czasie rzeczywistym, uzyskało ocenę pozytywną [50].

Warto również wspomnieć o badaniu Goto i wsp., w którym porównano różne metody diagnostyczne wykorzystywane do detekcji mutacji EGFR, w tym sekwencjonowanie metodą Sangera oraz PNA-LNA PCR clamp, a także Scorpion-ARMS, PCR-Invader oraz Cycleave PCR. Bezpośrednia zgodność dwóch dowolnych metod $\mathrm{w}$ analizie 116 materiałów utrwalonych FFPE wynosiła od $85,3 \%$ do $99,1 \%$. W 3,4\% przypadków dwie metody niezależnie wykryły różne mutacje $\mathrm{w}$ tym samym materiale, natomiast w kolejnych $6,9 \%$ stwierdzono występowanie wyników fałszywie ujemnych [51]. Najwyższy odsetek wyników wątpliwych, wynikających z braku zgodności metod, obserwowano w materiałach zawierających poniżej 40\% komórek nowotworowych, o średnicy analizowanego fragmentu tkanki do $9 \mathrm{~mm}$ oraz preparatach archiwalnych, przechowywanych dłużej niż 3 lata [51]. Rozbieżności pomiędzy metodami diagnostycznymi dotyczą przede wszystkim wyników fałszywie ujemnych. Podobny wniosek wynika z badania Ikedy i wsp., którzy analizowali materiały od chorych na NDRP za pomocą trzech wysokoczułych metod: MEPCR, PNA-LNA PCR clamp oraz PCR-Invader. Rozbieżność wyników stwierdzono w przypadku 5 materiałów. Co ważne wszyscy chorzy pozytywnie odpowiedzieli na leczenie EGFR-IKT [52].

Reasumując, podstawowym czynnikiem wpływającym na czułość i specyficzność detekcji mutacji genu EGFR są różnice w jakości DNA i procedurach izolacji między laboratoriami, stosowanie różnych odczynników, zróżnicowana konstrukcja samych testów, zwłaszcza sekwencji starterów i wielkości amplikonów PCR, a także zawartość komórek nowotworowych oraz wewnętrzna heterogenność materiałów NDRP [51].

\section{Detekcja mutacji genu EGFR w pozakomórkowym DNA we krwi chorych na NDRP jako uzupełnienie badania materiału tkankowego i komórkowego}

Analiza molekularna krwi obwodowej, szczególnie pod kątem markerów genetycznych zawartych w pozakomórkowej frakcji kwasów nukleinowych, jest obiecującym rozwiązaniem, które może w niedalekiej przyszłości znaleźć zastosowanie w diagnostyce. Podwyższony poziom pozakomórkowego DNA stwierdzany jest już we wczesnych stadiach klinicznych choroby nowotworowej układu oddechowego [53]. Ponadto, $\mathrm{w}$ pozakomórkowym materiale genetycznym krążącym we krwi chorych na NDRP możliwa jest identyfikacja tych samych zmian genetycznych (np. mutacji genów EGFR, KRAS) i/lub epigenetycznych (m.in. metylacja genów supresorowych), jakie są wykrywane w DNA izolowanym bezpośrednio z komórek nowotworowych [54, 55]. Wykazano, że wykrycie za pomocą wysokoczułej metody Scorpion-ARMS aktywującej mutacji EGFR w osoczu chorych na NDRP jest związane $\mathrm{z}$ wydłużoną mediana czasu przeżycia wolnego od progresji (PFS $=18,3$ mies.) w stosunku do chorych bez mutacji ( 4 mies.; $p=0,012$ ) lub z występującą mutacją T790M (3,9 mies.; $\mathrm{p}=0,008)$, u chorych leczonych docetakselem i erlotynibem [56]. Również w badaniu Brevet i wsp., gdzie do detekcji mutacji wykorzystano metody spektrome- 
trii masowej oraz ME-PCR, stwierdzono istotnie dłuższy czas przeżycia całkowitego (OS, overall survival) leczonych erlotynibem chorych na raka płuca z mutacją aktywującą genu EGFR wykrytą $\mathrm{w}$ materiale pozakomórkowego DNA z osocza i/ /lub tkance nowotworowej $(\mathrm{p}=0,002)$ [57]. Warto zauważyć, że zgodność wyników genotypowania mutacji EGFR w osoczu względem tkanki wynosiła $63 \%$ (18/31 chorych z mutacją). U dwóch chorych, u których stwierdzono obecność delecji w eksonie 19 genu EGFR jedynie w DNA z osocza uzyskano jednak pozytywną odpowiedź na terapię IKT [57].

Istotnie niższa czułość diagnostyczna analizy mutacji genu EGFR we krwi w porównaniu $\mathrm{z}$ oceną materiału pochodzącego z guza nowotworowego nie pozwala obecnie na jej wykorzystanie jako niezależnego narzędzia diagnostycznego. Prowadzone są jednak obiecujące badania nad detekcją mutacji EGFR w pozakomórkowym DNA z krwi obwodowej chorych na NDRP za pomocą wysokoczułych metod wykorzystujących PCR w czasie rzeczywistym, sekwencjonowanie nowej generacji czy technikę BEAMing. Ich stosowanie mogłoby przedstawiać szczególną wartość w sytuacji braku tkankowego lub cytologicznego materiału diagnostycznego, a także potencjalnie umożliwiać nieinwazyjne monitorowanie zmian profilu mutacji w trakcie terapii, na przykład wystąpienia mutacji T790M w toku leczenia EGFR-IKT [32, 58, 59]. Wydaje się również, że zastosowanie detekcji mutacji genu EGFR w pozakomórkowym DNA osocza chorych na niedrobnokomórkowego raka płuca stanie się w nieodległej przyszłości wartościowym uzupełnieniem diagnostyki prowadzonej w materiale tkankowym i cytologicznym.

\section{Podsumowanie}

Pomimo braku jednoznacznie określonego „złotego standardu” w diagnostyce mutacji genu EGFR, analiza molekularna materiału tkankowego i komórkowego od chorych na NDRP jest skuteczna, gdy wykonuje się ją za pomocą odpowiednio dobranych technik pośrednich i/lub bezpośrednich. Do niedawna najpopularniejszą w Polsce metodą diagnostyki mutacji genu EGFR było sekwencjonowanie metodą Sangera [49]. Obecnie coraz więcej ośrodków wykorzystuje techniki oparte na PCR w czasie rzeczywistym a na polskim rynku dostępnych jest kilka komercyjnych zestawów diagnostycznych certyfikowanych do diagnostyki in vitro (CE-IVD). Niewątpliwie jednak przyszłość diagnostyki molekularnej należy do technik wysokoprzepustowych. Warto wspo- mnieć, że pod koniec 2013 roku amerykańska Agencja Żywności i Leków (FDA, Food and Drug Administration) po raz pierwszy dopuściła do sprzedaży jako wyroby medyczne system sekwencjonowania nowej generacji oraz dedykowane zestawy odczynnikowe do stosowania w diagnostyce klinicznej [60]. Bez względu na wybór techniki biologii molekularnej, kluczowe znaczenie dla wykonywania wiarygodnych oznaczeń ma zawsze odpowiednia walidacja diagnostyczna wykorzystywanych testów, a także stosowanie zewnętrznej kontroli jakości (EQA) badań genetycznych. Punktem wyjścia przy opracowywaniu i wdrażaniu procedur diagnostycznych powinna być zatem znajomość aktualnych zaleceń, opisujących ogólnie przyjęte zasady przygotowania materiału biologicznego i analizy mutacji EGFR, opartych na wynikach prac doświadczalnych oraz opinii specjalistów w tej dziedzinie.

\section{Konflikt interesów}

Autorzy deklarują brak konfliktu interesów.

\section{Piśmiennictwo:}

1. Chorostowska-Wynimko J., Skroński M., Szpechciński A. Molekularne markery prognostyczne i predykcyjne w diagnostyce niedrobnokomórkowego raka płuca. Onkologia Info 2011; VIII: 160-167.

2. Cheng L., Alexander R.E., Maclennan G.T. i wsp. Molecular pathology of lung cancer: key to personalized medicine. Mod. Pathol. 2012; 25: 347-369.

3. Hata A., Yoshioka H., Fujita S. i wsp.Complex mutations in the epidermal growth factor receptor gene in non-small cell lung cancer. J. Thorac. Oncol. 2010; 5: 1524-1528.

4. Liang Z., Zhang J., Zeng X., Gao J., Wu S., Liu T. Relationship between EGFR expression, copy number and mutation in lung adenocarcinomas. BMC Cancer 2010; 10: 376.

5. Krawczyk P., Ramlau R., Powrózek T. i wsp. Wykrywalność mutacji w genie EGFR u chorych na niedrobnokomórkowego raka płuca w wybranych ośrodkach w Polsce zaangażowanych w diagnostykę molekularną. Kardiochirurgia i Torakochirurgia Polska 2012; 9: 431-438.

6. Kobayashi S., Boggon T.J., Dayaram T. i wsp. EGFR mutation and resistance of non-small-cell lung cancer to gefitinib. $\mathrm{N}$. Engl. J. Med. 2005; 352: 786-792.

7. Yu H.A., Arcila M.E., Rekhtman N. i wsp. Analysis of tumor specimens at the time of acquired resistance to EGFR-TKI therapy in 155 patients with EGFR-mutant lung cancers. Clin Cancer Res 2013; 19: 2240-2247.

8. Inukai M., Toyooka S., Ito S. i wsp. Presence of epidermal growth factor receptor gene T790M mutation as a minor clone in non-small cell lung cancer. Cancer Res 2006; 66: 7854-7858.

9. Yasuda H., Park E., Yun C.H. i wsp. Structural, Biochemical, and Clinical Characterization of Epidermal Growth Factor Receptor (EGFR) Exon 20 Insertion Mutations in Lung Cancer. Sci. Transl. Med. 2013; 5: 216 ra177.

10. Pirker R., Herth F.J., Kerr K.M. i wsp. Consensus for EGFR mutation testing in non-small cell lung cancer: results from a European workshop. J. Thorac. Oncol. 2010; 5: 1706-1713.

11. Lindeman N.I., Cagle P.T., Beasley M.B. i wsp. Molecular Testing Guideline for Selection of Lung Cancer Patients for EGFR and ALK Tyrosine Kinase Inhibitors: Guideline from the College of American Pathologists, International Association for the Study of Lung Cancer, and Association for Molecular Pathology. J. Thorac. Oncol. 2013; 8: 823-859 
12. Travis W.D., Rekhtman N. Pathological diagnosis and classification of lung cancer in small biopsies and cytology: strategic management of tissue for molecular testing. Semin. Respir. Crit. Care Med. 2011; 32: 22-31.

13. Lewandowska M., Starzyński W., Kowalewski J. Ocena częstości występowania mutacji w genie EGFR i współwystępowania mutacji EGFR i KRAS metodą reakcji łańcuchowej polimerazy w czasie rzeczywistym u chorych na raka gruczołowego płuca - czy kliniczno-patologiczny model kwalifikacji pacjenta do leczenia celowanego może mieć wpływ na czas uzyskania wyniku genetycznego? Kardiochirurgia i Torakochirurgia Polska 2012; 9: 443-451.

14. Pao W., Ladanyi M. Epidermal growth factor receptor mutation testing in lung cancer: searching for the ideal method. Clin Cancer Res 2007; 13: 4954-4955.

15. Taniguchi K., Okami J., Kodama K., Higashiyama M., Kato K. Intratumor heterogeneity of epidermal growth factor receptor mutations in lung cancer and its correlation to the response to gefitinib. Cancer Sci. 2008; 99: 929-935.

16. Sun L., Zhang Q., Luan H., Zhan Z., Wang C., Sun B. Comparison of KRAS and EGFR gene status between primary non-small cell lung cancer and local lymph node metastases: implications for clinical practice. J. Exp. Clin. Cancer Res. 2011; 30: 30.

17. Huijsmans C.J., Damen J., van der Linden J.C., Savelkoul P.H., Hermans M.H. Comparative analysis of four methods to extract DNA from paraffin-embedded tissues: effect on downstream molecular applications. BMC Res Notes 2010; 3: 239.

18. AstraZeneca - Mutation detection techniques. http://www. egfr-info.co.uk/EGFR-exon/egfr-mutation-detection/.

19. Sanger F., Nicklen S., Coulson A.R. DNA sequencing with chain-terminating inhibitors. Proc Natl Acad Sci U S A 1977; 74: 5463-5467.

20. McCourt C.M., McArt D.G., Mills K. i wsp. Validation of next generation sequencing technologies in comparison to current diagnostic gold standards for BRAF, EGFR and KRAS mutational analysis. PLoS One 2013; 8: e69604.

21. Dahse R., Berndt A., Dahse A.K., Kosmehl H. Two allele-specific PCR assays for screening epidermal growth factor receptor gene hotspot mutations in lung adenocarcinoma. Mol. Med. Rep. 2008; 1: 45-50.

22. Kimura H., Fujiwara Y., Sone T. i wsp. High sensitivity detection of epidermal growth factor receptor mutations in the pleural effusion of non-small cell lung cancer patients. Cancer Sci. 2006; 97: 642-648.

23. Pennycuick A., Simpson T., Crawley D. i wsp. Routine EGFR and KRAS Mutation analysis using COLD-PCR in non-small cell lung cancer. Int. J. Clin. Pract. 2012; 66: 748-752.

24. Nagai Y., Miyazawa H., Huqun i wsp. Genetic heterogeneity of the epidermal growth factor receptor in non-small cell lung cancer cell lines revealed by a rapid and sensitive detection system, the peptide nucleic acid-locked nucleic acid PCR clamp. Cancer Res. 2005; 65: 7276-7282.

25. Miyano S., Hanazawa K., Kitabatake T., Fujisawa M., Kojima K. Detecting KRAS mutations in peripheral blood of colorectal cancer patients by peptide nucleic acid clamp PCR. Exp. Ther. Med. 2012; 4: 790-794.

26. Araki T., Shimizu K., Nakamura T. i wsp. Clinical screening assay for EGFR exon 19 mutations using PNA-clamp smart amplification process version 2 in lung adenocarcinoma. Oncol. Rep. 2011; 26: 1213-1219.

27. Asano H., Toyooka S., Tokumo M. i wsp. Detection of EGFR gene mutation in lung cancer by mutant-enriched polymerase chain reaction assay. Clin. Cancer Res. 2006; 12: 43-48.

28. Wojas-Krawczyk K., Skroński M., Krawczyk P. i wsp. EGFR activating mutations detected by different PCR techniques in Caucasian NSCLC patients with CNS metastases: short report. Clin. Exp. Metastasis 2013; 30: 1063-1071.

29. Smouse J.H., Cibas E.S., Jänne P.A., Joshi V.A., Zou K.H., Lindeman N.I. EGFR mutations are detected comparably in cytologic and surgical pathology specimens of nonsmall cell lung cancer. Cancer 2009; 117: 67-72.

30. Endo K., Konishi A., Sasaki H. i wsp. Epidermal growth factor receptor gene mutation in non-small cell lung cancer using highly sensitive and fast TaqMan PCR assay. Lung Cancer 2005; 50: $375-384$
31. Dressman D., Yan H., Traverso G., Kinzler K.W., Vogelstein B. Transforming single DNA molecules into fluorescent magnetic particles for detection and enumeration of genetic variations. Proc. Natl. Acad. Sci U S A 2003; 100; 8817-8822.

32. Taniguchi K., Uchida J., Nishino K. i wsp. Quantitative detection of EGFR mutations in circulating tumor DNA derived from lung adenocarcinomas. Clin. Cancer Res. 2011; 17; 7808-7815.

33. Wang J., Ramakrishnan R., Tang Z. i wsp. Quantifying EGFR alterations in the lung cancer genome with nanofluidic digital PCR arrays. Clin. Chem. 2010; 56: 623-632.

34. Yatabe Y, Hida T, Horio Y, Kosaka T, Takahashi T, Mitsudomi T. A rapid, sensitive assay to detect EGFR mutation in small biopsy specimens from lung cancer. J. Mol. Diagn. 2006: 8: 335-341.

35. Naoki K., Soejima K., Okamoto H. i wsp. The PCR-invader method (structure-specific 5' nuclease-based method), a sensitive method for detecting EGFR gene mutations in lung cancer specimens; comparison with direct sequencing. Int. J. Clin. Oncol. 2011; 16: 335-344.

36. Su K.Y., Chen H.Y., Li K.C. i wsp. Pretreatment epidermal growth factor receptor (EGFR) T790M mutation predicts shorter EGFR tyrosine kinase inhibitor response duration in patients with non-small-cell lung cancer. J. Clin. Oncol. 2012; 30: 433440 .

37. Marchetti A., Martella C., Felicioni L. i wsp. EGFR mutations in non-small-cell lung cancer: analysis of a large series of cases and development of a rapid and sensitive method for diagnostic screening with potential implications on pharmacologic treatment. J. Clin. Oncol. 2005; 23: 857-865.

38. Nomoto K., Tsuta K., Takano T. i wsp. Detection of EGFR mutations in archived cytologic specimens of non-small cell lung cancer using high-resolution melting analysis. Am. J. Clin. Pathol. 2006; 126: 608-615.

39. Do H., Krypuy M., Mitchell P.L., Fox S.B., Dobrovic A. High resolution melting analysis for rapid and sensitive EGFR and KRAS mutation detection in formalin fixed paraffin embedded biopsies. BMC Cancer 2008; 8: 142.

40. Sueoka N., Sato A., Eguchi H. i wsp. Mutation profile of EGFR gene detected by denaturing high-performance liquid chromatography in Japanese lung cancer patients. J. Cancer Res. Clin. Oncol. 2007; 133: 93-102.

41. Yu J., Kane S., Wu J. i wsp. Mutation-specific antibodies for the detection of EGFR mutations in non-small-cell lung cancer. Clin. Cancer Res. 2009; 15: 3023-3028.

42. Hasanovic A., Ang D., Moreira A.L., Zakowski M.F. Use of mutation specific antibodies to detect EGFR status in small biopsy and cytology specimens of lung adenocarcinoma. Lung Cancer 2012; 77: 299-305.

43. Kitamura A., Hosoda W., Sasaki E., Mitsudomi T., Yatabe Y. Immunohistochemical detection of EGFR mutation using mutation-specific antibodies in lung cancer. Clin. Cancer Res. 2010; 16: 3349-3355.

44. Brevet M., Arcila M., Ladanyi M. Assessment of EGFR mutation status in lung adenocarcinoma by immunohistochemistry using antibodies specific to the two major forms of mutant EGFR. J. Mol. Diagn. 2010; 12: 169-176.

45. Kato Y., Peled N., Wynes M.W. i wsp. Novel epidermal growth factor receptor mutation-specific antibodies for non-small cell lung cancer: immunohistochemistry as a possible screening method for epidermal growth factor receptor mutations. J. Thorac. Oncol. 2010; 5: 1551-1558.

46. Han H.S., Lim S.N., An J.Y. i wsp. Detection of EGFR mutation status in lung adenocarcinoma specimens with different proportions of tumor cells using two methods of differential sensitivity. J. Thorac. Oncol. 2012; 7: 355-364.

47. Zhou Q., Zhang X.C., Chen Z.H. i wsp. Relative abundance of EGFR mutations predicts benefit from gefitinib treatment for advanced non-small-cell lung cancer. J. Clin. Oncol. 2011; 29: 3316-3321.

48. Skroński M., Chorostowska-Wynimko J., Szczepulska E. i wsp. Reliable detection of rare mutations in EGFR gene codon L858 by PNA-LNA PCR clamp in non-small cell lung cancer. Adv. Exp. Med. Biol. 2013; 756: 321-331.

49. Tysarowski A., Kowalczuk O., Chyczewski L. i wsp. Walidacja wybranych ośrodków zaangażowanych w diagnostykę moleku- 
larną chorób nowotworowych w zakresie oznaczania mutacji w genie EGFR1. Onkologia w Praktyce Klinicznej 2011; 7: 138-145.

50. Normanno N., Pinto C., Taddei G. i wsp. Results of the First Italian External Quality Assurance Scheme for somatic EGFR mutation testing in non-small-cell lung cancer. J. Thorac. Oncol. 2013; 8: 773-778.

51. Goto K., Satouchi M., Ishii G. i wsp. An evaluation study of EGFR mutation tests utilized for non-small-cell lung cancer in the diagnostic setting. Ann. Oncol. 2012; 23: 2914-2919.

52. Ikeda T., Nakamura Y., Yamaguchi H. i wsp. Direct comparison of 3 PCR methods in detecting EGFR mutations in patients with advanced non-small-cell lung cancer. Clin. Lung Cancer 2012; 13: 369-374.

53. Szpechcinski A., Chorostowska-Wynimko J., Kupis W. i wsp. Quantitative analysis of free-circulating DNA in plasma of patients with resectable NSCLC. Expert Opin. Biol. Ther. 2012; 12 (supl. 1): S3-9.

54. Chorostowska-Wynimko J., Szpechcinski A. The impact of genetic markers on the diagnosis of lung cancer: a current perspective. J. Thorac. Oncol. 2007; 2: 1044-1051.
55. Krawczyk P., Chorostowska-Wynimko J., Skroński M. i wsp. Czy oznaczanie mutacji w genie EGFR we krwi obwodowej zrewolucjonizuje kwalifikację do terapii inhibitorami kinazy tyrozynowej EGFR? Onkologia Polska 2011; 14: 54-63.

56. Mack P.C., Holland W.S., Burich R.A. i wsp. EGFR mutations detected in plasma are associated with patient outcomes in erlotinib plus docetaxel-treated non-small cell lung cancer. J.Thorac. Oncol. 2009; 4: 1466-1472.

57. Brevet M., Johnson M.L., Azzoli C.G., Ladanyi M. Detection of EGFR mutations in plasma DNA from lung cancer patients by mass spectrometry genotyping is predictive of tumor EGFR status and response to EGFR inhibitors. Lung Cancer 2011; 73: 96-102.

58. Mok T., Lee J.S., Yu C.J. i wsp. Dynamic change in plasma EGFR mutation DNA in response to first line therapy for advanced stage non-small cell lung cancer (NSCLC). 15th World Conference on Lung Cancer, Sydney, Australia; Journal of Thoracic Oncology 2013; S133-S134.

59. Forshew T., Murtaza M., Parkinson C., i wsp. Noninvasive identification and monitoring of cancer mutations by targeted deep sequencing of plasma DNA. Sci. Transl. Med. 2012; 4: 136ra168.

60. Collins F.S., Hamburg M.A. First FDA Authorization for NextGeneration Sequencer. N. Engl. J. Med. 2013; 369: 2369-2371. 